\title{
Amphibia, Anura, Hylidae, Boana wavrini (Parker, 1936): distribution extension in the Colombian Llanos
}

\author{
Andrés Rymel Acosta-Galvis, ${ }^{1}$ Luis Eduardo Rojas-Murcia ${ }^{2}$ \\ 1 Subdirección de Investigaciones, Colecciones Biológicas, Instituto de Investigación de Recursos Biológicos Alexander von Humboldt, Carrera 8 \\ \# 15-08, Claustro de San Agustín, Villa de Leyva, Boyacá, Colombia. 2 Grupo de biología y conservación, Universidad Pedagógica y Tecnológica \\ de Colombia UPTC, Tunja, Boyacá, Colombia. \\ Corresponding author: Andrés Rymel Acosta Galvis, aacosta@humboldt.org.co
}

\begin{abstract}
We report the presence of Boana wavrini in Arauca and Vichada departments (Llanos of Colombia). These localities extend the known range of this species by more than $283 \mathrm{~km}$ to the north from the previously known occurrences. In addition, we describe some aspects of the natural history of this species.
\end{abstract}

\section{Key words}

Colombia; savannas; llanos; Orinoco River; range extension; tadpoles; habitat.

Academic editor: Marcelo Gehara | Received 11 March 2017 | Accepted 6 September 2017 | Published 27 October 2017

Citation: Acosta-Galvis ARA, Rojas-Murcia LER (2017) Amphibia, Anura, Hylidae, Boana wavrini (Parker, 1936): distribution extension in the Colombian Llanos. Check List 13 (5): 663-670. https://doi.org/10.15560/13.5.663

\section{Introduction}

The Neotropical genus Boana Gray, 1825 contains 92 described species distributed throughout the Neotropics from Nicaragua to Argentina (Frost 2017). In Colombia, there are 22 species of Boana mainly found in the lowlands (Acosta-Galvis 2017). Three of these species (Boana boans (Linnaeus, 1758), B. geographica (Spix, 1824), and B. wavrini (Parker, 1931)) stand out by having specialized nesting behavior; they almost always select sites on the edges of bodies of water where they build their nests. These species can be recognized by the presence of a reticulated palpebral membrane and small dermal projections on the heels, characters that place them in the Boana semilineata species group (Hoogmoed 1990, Martins and Moreira 1991, Faivovich et al. 2005).

One of these species, $B$. wavrini, broadly encompass- es central Amazonia (80-400 m above sea level) in the state of Amazonas, southern Venezuela and in the states of Amazonas, Roraima, Pará, Rondônia, and Mato Grosso, Brazil (Hoogmoed 1990, Martins and Moreira 1991, Gorzula and Senaris 1998). Additionally its distribution in Colombia is geographically associated with the Guiana Shield along the Orinoco River, and it can only be found in the Guainía (Puerto Inírida Municipality), Vaupés (Caparú Biological Station, Taraira Municipality) and Vichada (El Tuparro National Natural Park at $\mathrm{Cu}-$ maribo Municipality) departments (Ruiz-Carranza et al. 1996, Acosta-Galvis 2000, Lynch and Vargas-Ramirez 2000, Lynch and Suárez-Mayorga 2001, 2011). Here we report new records of $B$. wavrini in other Colombian departments, which extend the known distribution of this species $283 \mathrm{~km}$ to the north of previously known occurrences. 


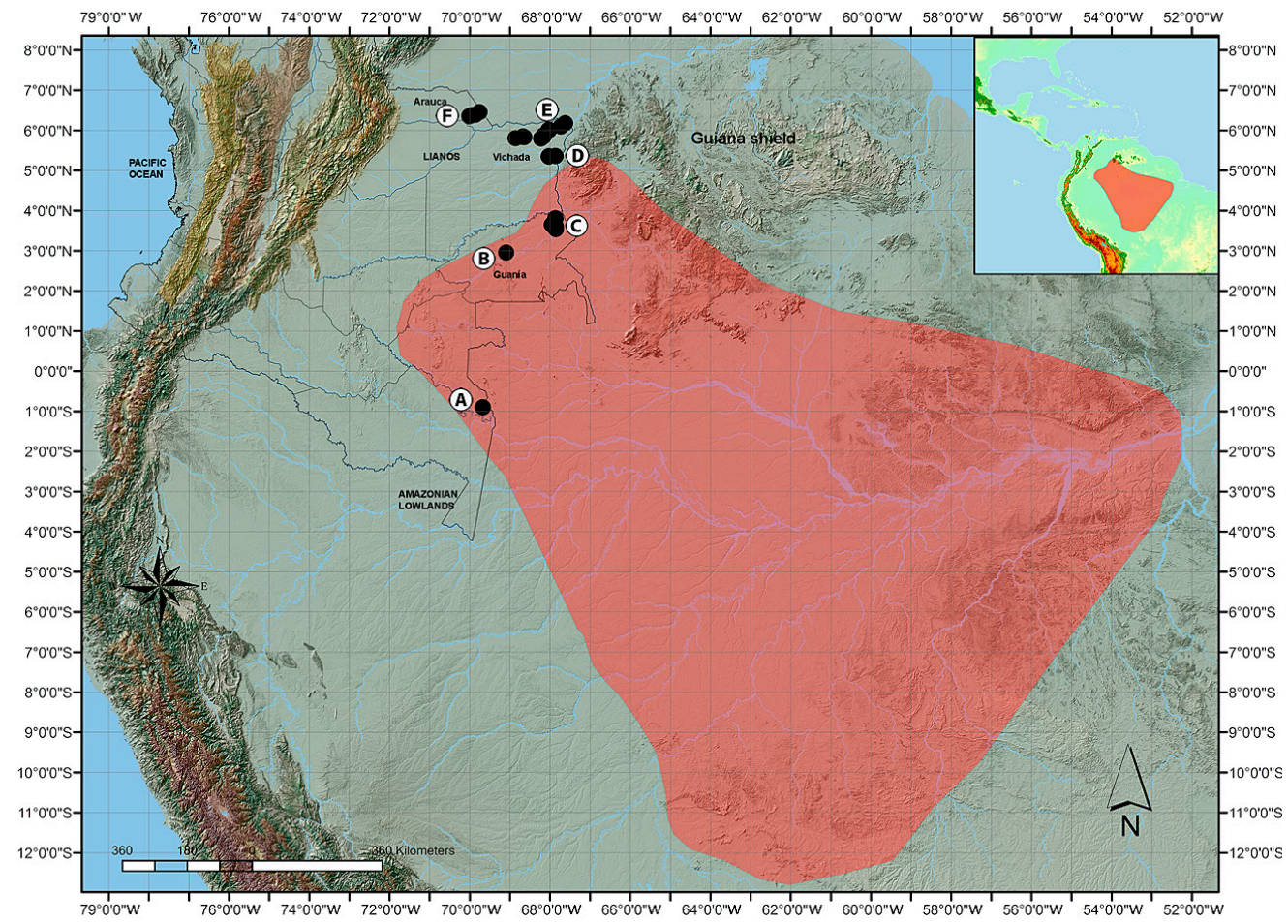

Figure 1. Currently known distribution of Boana wavrini (red Polygon, IUCN Red List) based on published scientific literature (Hoogmoed 1990, Martins and Moreira 1991, Lynch and Vargas-Ramirez 2000). A-C. Previous Colombian localities published (Acosta-Galvis 2000, Lynch and Vargas-Ramirez 2000, Lynch and Suárez-Mayorga 2001). D. Additional specimens deposited in the collection of amphibians of the Humboldt Institute (IAvH-Am), and not published in the scientific literature; from Cumaribo municipality (Tuparro, Natural National Park), Vichada Department (IAvH-Am-7515-7, IAvH-Am-7533, IAvH-Am-7547-9, IAvH-Am-7553-4, IAvH-Am-7598). E. New records at Bita River, Vichada Department. F. New records in Arauca Department.

\section{Methods}

We examined 57 specimens, of which 8 were previously deposited in the Amphibian Collection (Table 1, Fig. 1) of the Alexander von Humboldt Biological Resources Research Institute, Villa de Leyva Boyacá, Colombia (IAvH-Am); 49 were collected during 4 separate field expeditions to Vichada and Arauca departments, including both in the rainy and dry seasons (Table 1, Figs 2, 8). The specimens were collected using active manual capture methods that include aquatic and terrestrial transects associated with riparian landscapes. Specimens were euthanized in benzocaine and fixed in $10 \%$ formalin solution, then transferred to $70 \%$ ethanol. Identification was made using Hoogmoed (1990) and voucher specimens were deposited in IAvH-Am (Table 1). We also examined additional specimens of $B$. wavrini from other nearby localities (Fig. 1A-C).

\section{Results}

Boana wavrini is a large frog (SVL 75-113 mm) that can be distinguished from $B$. boans, according to Hoogmoed (1990), by the following features (those of B. boans in parentheses, Fig. 3): Throat in males with dark radiating stripes (Fig. 3A), rounded spots separated by dark network (uniform in B. boans, Fig. 3B). Iris color in life reddish brown (Fig. 3C) to grayish (golden in B. boans, Fig. 3D). Fingers extensively webbed, fourth finger with penultimate phalanx free (webbing reaches disc in $B$. boans). Subarticular tubercles fingers pronounced (not very distinct in B. boans). Discs fingers distinctly smaller than tympanum (completely covering tympanum in B. boans). Webbing of the fourth toe does not reach disc (reaches disc in $B$. boans). Median ridge on side of tibia absent (on posterior region, connected with heel appendage in B. boans). Heel appendage transverse ridge with lateral triangular flap (Fig. 3E) (transverse ridge with small triangular tubercle in B. boans, Fig. 3F) Canthus rostralis straight (concave in B. boans), and snout anteriorly truncate (concave in B. boans).

As part of the results obtained from 4 field expeditions, we also recorded natural history data on Colombian populations of $B$. wavrini (Table 1, Fig. 1). In the dry season (January 2016), ARA obtained 14 specimens from the ground on sandbanks or from shrubs in gallery forests (Site B, Table 1, Figs 2, 5). These series consist of 6 adult females (SVL 85.7-101.0 mm), together with 8 adult males (SVL 85.6-98.3 mm); 1 adult male (IAvHAm-11858) was recorded vocalizing on dry shrubs at 30 $\mathrm{cm}$ above the ground at an environmental temperature of $32{ }^{\circ} \mathrm{C}$ and $68 \%$ relative humidity. Additional specimens (site C, Table 1, Fig. 2) were obtained by ARA from the edge of the Bita River. The series includes 5 females (SVL 81.7-98.8 mm) and 7 males (SVL 91.0-101.2 mm) that were located vocalizing at the base of the trees and shrubs along shore. Two additional specimens that include 1 juvenile IAvH-Am-11873 (SVL $71.0 \mathrm{~mm}$ ) and 1 adult female IAvH-Am-11874 (SVL $94.3 \mathrm{~mm}$ ) were located in transitional areas between morichales (the local 
Table 1. List of localities with records of Boana wavrini in the Colombian Llanos. The presence of each voucher in individual localities, date, and season of the year (indicated with an " $\mathrm{X}$ ") are included.

\begin{tabular}{|c|c|c|c|c|c|c|c|c|}
\hline \multirow[b]{2}{*}{ Locality } & \multirow[b]{2}{*}{$\begin{array}{l}\text { Latitude } \\
\text { (W) }\end{array}$} & \multirow[b]{2}{*}{$\begin{array}{l}\text { Longitude } \\
\text { (W) }\end{array}$} & \multirow{2}{*}{$\begin{array}{l}\overline{\underline{\xi}} \\
\dot{\overrightarrow{\mathrm{d}}}\end{array}$} & \multirow[b]{2}{*}{ Geographical location } & \multirow[b]{2}{*}{ Date } & \multicolumn{2}{|c|}{ Season } & \multirow[b]{2}{*}{ Voucher specimens } \\
\hline & & & & & & tà & 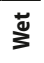 & \\
\hline Site A (Fig. 2) & $06^{\circ} 05^{\prime} 40^{\prime \prime} \mathrm{N}$ & $67^{\circ} 43^{\prime} 34^{\prime \prime}$ & 35 & $\begin{array}{l}\text { Lower Bita River, La Pedregoza Natural } \\
\text { Reserve,Vereda Caño Negro, Puerto Carreño } \\
\text { Municipality ,Vichada Department (Fig. 4) }\end{array}$ & 7 Aug. 2012 & & $x$ & Adult males: IAvH-Am-11584-6 \\
\hline Site B (Fig. 2) & $05^{\circ} 51^{\prime} 02^{\prime \prime} \mathrm{N}$ & $68^{\circ} 40^{\prime} 10^{\prime \prime}$ & 71 & $\begin{array}{l}\text { Middle Bita River, La Danta Creek, Maracana } \\
\text { farm, La Primavera Municipality, Vichada } \\
\text { Department (Fig. 5) }\end{array}$ & $\begin{array}{l}13-15 \text { Jan. } \\
2016\end{array}$ & $x$ & & $\begin{array}{l}\text { Adult males IAvH-Am-11855-8, IAvH-Am-11860, } \\
\text { IAvH-Am-11862 and IAvH-Am-11865; adult females } \\
\text { IAvH-Am-11853-4, IAvH-Am-11859, } \\
\text { IAvH-Am-11863-4 and IAvH-Am-11866 }\end{array}$ \\
\hline Site C (Fig. 2) & $\begin{array}{l}05^{\circ} 51^{\prime} 38^{\prime \prime}- \\
05^{\circ} 52^{\prime} 32^{\prime \prime}\end{array}$ & $\begin{array}{l}068^{\circ} 09^{\prime} 18^{\prime \prime}- \\
068^{\circ} 09^{\prime} 55^{\prime \prime}\end{array}$ & $\begin{array}{c}48- \\
62\end{array}$ & $\begin{array}{l}\text { Middle Bita River, Mi Familia farm, Puerto } \\
\text { Carreño Municipality, Vichada Department }\end{array}$ & $\begin{array}{l}\text { 18-19 Jan. } \\
2016\end{array}$ & $x$ & & $\begin{array}{l}\text { Adult males IAvH-Am-11867-9, IAvH-Am-11872, } \\
\text { IAvH-Am-11876-7, IAvH-Am-11881; adult females } \\
\text { IAvH-Am-11870-1, 11874, IAvH-Am-11878-9, IAvH- } \\
\text { Am-11882; juvenile IAvH-Am-11873 }\end{array}$ \\
\hline Site D (Fig. 2) & $05^{\circ} 49^{\prime} 45^{\prime \prime} \mathrm{N}$ & $068^{\circ} 11^{\prime} 30^{\prime \prime}$ & 54 & $\begin{array}{l}\text { Middle Bita River, Site Anakay (base camp), } \\
\text { Puerto Carreño Municipality, Vichada } \\
\text { Department }\end{array}$ & 20 Jan. 2016 & $x$ & & $\begin{array}{l}\text { Adult males IAvH-Am-11883-5; juveniles } \\
\text { IAvH-Am-11875, IAvH-Am-11880, IAvH-Am-11884 }\end{array}$ \\
\hline $\begin{array}{l}\text { Site E (Fig. 2, } \\
\text { Table 2) }\end{array}$ & $05^{\circ} 48^{\prime} 04^{\prime \prime} \mathrm{N}$ & $068^{\circ} 13^{\prime} 12^{\prime \prime}$ & 65 & $\begin{array}{l}\text { Middle Bita River, Puerto Carreño Municipality, } \\
\text { Vichada Department }\end{array}$ & 19 Jan. 2016 & $x$ & & $\begin{array}{l}\text { Tadpole stage } 28 \text { sensu Gosner (1960) } \\
\text { IAvH-Am-11931 }\end{array}$ \\
\hline $\begin{array}{l}\text { Site F (Fig. 2, } \\
\text { Table 2) }\end{array}$ & $05^{\circ} 51^{\prime} 09^{\prime \prime} \mathrm{N}$ & $068^{\circ} 09^{\prime} 40^{\prime \prime}$ & 63 & $\begin{array}{l}\text { Middle Bita River, Puerto Carreño Municipality, } \\
\text { Vichada Department }\end{array}$ & 21 Jan. 2016 & $x$ & & $\begin{array}{l}\text { Tadpole stage } 39 \text { sensu Gosner (1960) } \\
\text { IAvH-Am-11930; tadpole stage } 28 \text { sensu Gosner } \\
\text { (1960) IAvH-Am-11933 }\end{array}$ \\
\hline Site G (Fig. 2) & $05^{\circ} 52^{\prime} 44^{\prime \prime}$ & $068^{\circ} 09^{\prime} 15^{\prime \prime}$ & 63 & $\begin{array}{l}\text { Middle Bita River, El Mosco Creek, Puerto Carreño } \\
\text { Municipality, Vichada Department }\end{array}$ & 23 Jan. 2016 & $x$ & & $\begin{array}{l}\text { Tadpole stage } 26-28 \text { sensu Gosner (1960) } \\
\text { IAvH-Am-11934 }\end{array}$ \\
\hline $\begin{array}{l}\text { Site H (Fig. 2, } \\
\text { Table 2) }\end{array}$ & $05^{\circ} 51^{\prime} 09^{\prime \prime}$ & $068^{\circ} 09^{\prime} 40^{\prime \prime}$ & 63 & $\begin{array}{l}\text { Middle Bita River, El Tijero Creek, Puerto Carreño } \\
\text { Municipality, Vichada Department }\end{array}$ & $23 \mathrm{Jan} .2016$ & $x$ & & $\begin{array}{l}\text { Tadpoles stages } 28-39 \text { sensu Gosner (1960) } \\
\text { IAvH-Am-11932 }\end{array}$ \\
\hline Site I (Fig. 2) & $05^{\circ} 48^{\prime} 22^{\prime \prime}$ & $068^{\circ} 51^{\prime} 28^{\prime \prime}$ & 61 & $\begin{array}{l}\text { Middle Bita River, La Florida Farm, La Primavera } \\
\text { Municipality, Vichada Department }\end{array}$ & 25 May 2016 & & $x$ & Adult female IAvH-Am-13878 \\
\hline Site J (Fig. 8) & $06^{\circ} 27^{\prime} 20^{\prime \prime}$ & $069^{\circ} 45^{\prime} 12^{\prime \prime}$ & 96 & $\begin{array}{l}\text { Araguato Creek, Cravo Norte Municipality, } \\
\text { Arauca Department }\end{array}$ & 20 Apr. 2016 & & $x$ & Adult male IAvH-Am-14360 \\
\hline Site K (Fig. 8) & $06^{\circ} 24^{\prime} 49^{\prime \prime}$ & $069^{\circ} 51^{\prime} 32^{\prime \prime}$ & 95 & $\begin{array}{l}\text { La Palmira Farm, Cravo Norte Municipality, } \\
\text { Arauca Department }\end{array}$ & 20 Apr. 2016 & & $\mathrm{x}$ & Heard by LER \\
\hline Site L (Fig. 8) & $06^{\circ} 21^{\prime} 19^{\prime \prime}$ & $70^{\circ} 0^{\prime} 37.8^{\prime \prime}$ & 96 & $\begin{array}{l}\text { La Aurora Farm, Cravo Norte Municipality, Arauca } \\
\text { Department }\end{array}$ & May 2016 & & $x$ & Heard by LER \\
\hline Site M (Fig. 8) & $06^{\circ} 22^{\prime} 45^{\prime \prime}$ & $69^{\circ} 05^{\prime} 44^{\prime \prime}$ & 100 & $\begin{array}{l}\text { La Aurora Farm, Cravo Norte Municipality, Arauca } \\
\text { Department }\end{array}$ & 1 May 2016 & & $x$ & Adult male IAvH-Am-14361 \\
\hline
\end{tabular}

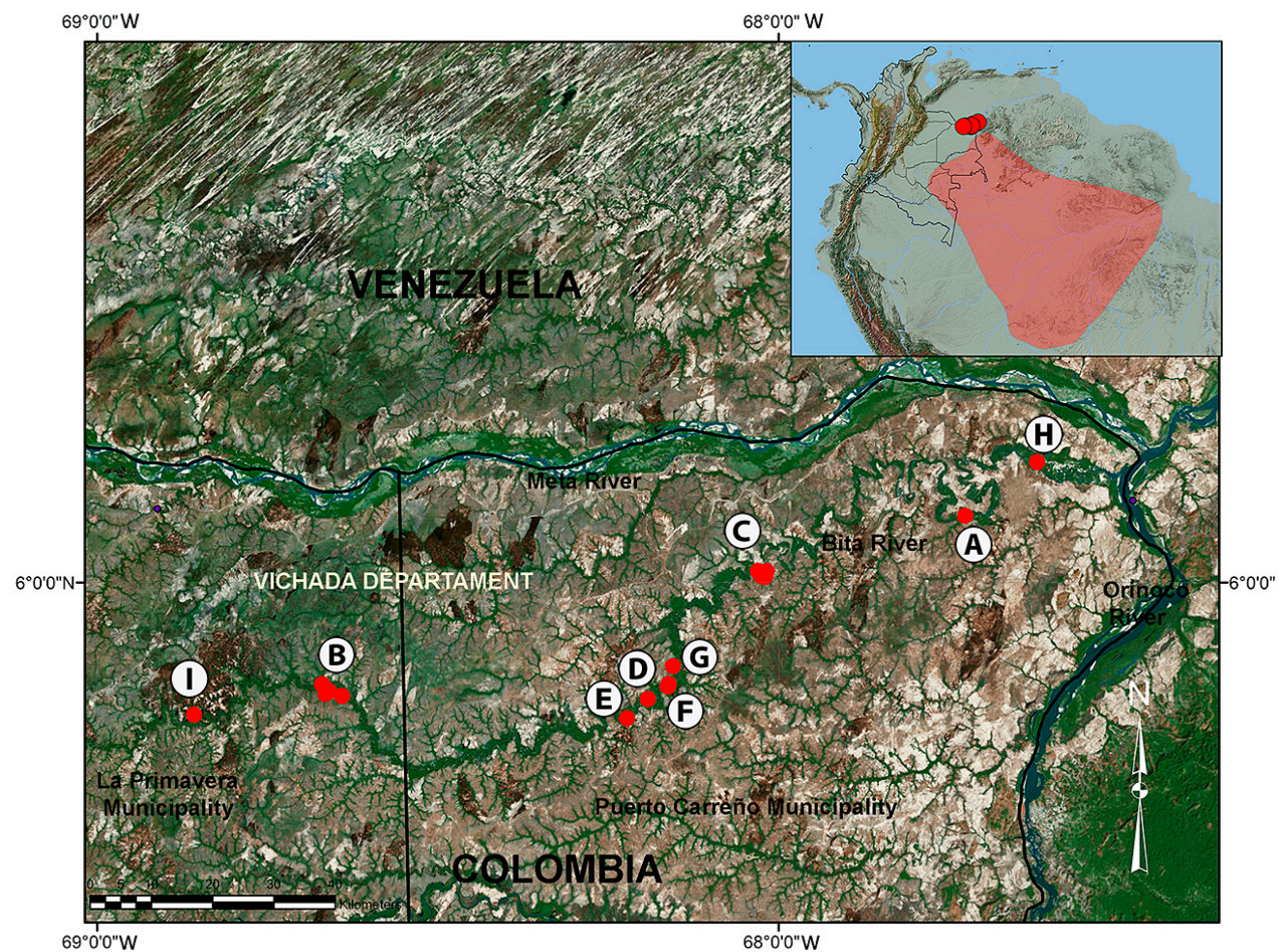

Figure 2. New records of Boana wavrini at Bita River, Vichada Department, in Llanos of Colombia (Table 1). Site A. Puerto Carreño municipality at Vereda Caño Negro, La Pedregoza Natural Reserve. Site B. La Danta stream afferent to the Bita River, at Maracana farm. Site C. Mi Familia farm, Puerto Carreño municipality. Site D. Middle Bita River at Anakay. Site E. Middle Bita River drainage. Site F. The old channel at Bita River Site G. El Mosco Creek. Site H. El Tijero Creek Site I. La Primavera Municipality, La Florida Farm. 

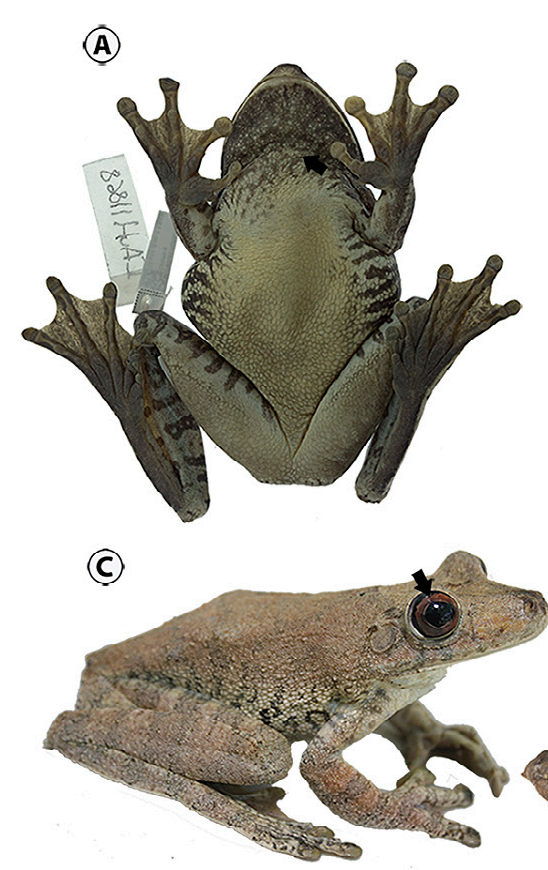

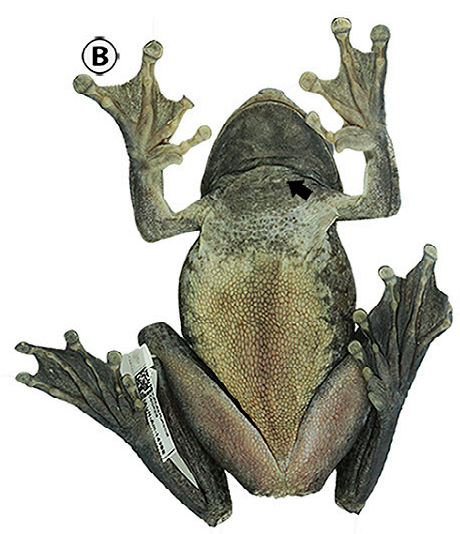

(D)

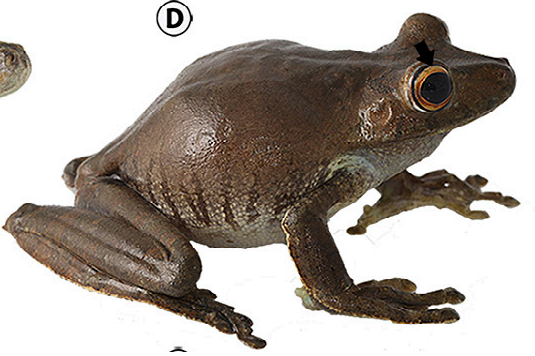

(E)

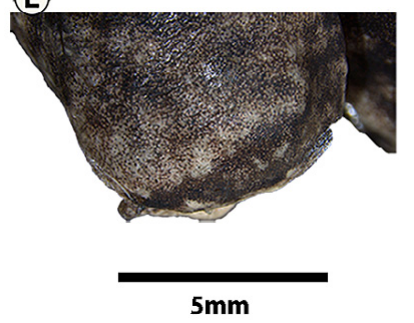

(F)

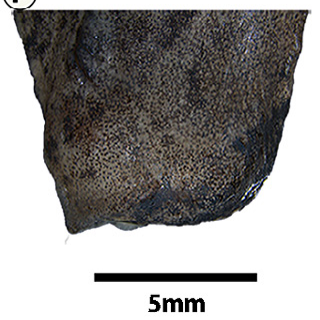

Figure 3. Morphological characters differences between Boana wavrini and B. boans. A. Adult male of B. wavrini IAvH 11868 (SVL $92.3 \mathrm{~mm}$ ) from Bita River, Vichada, Colombia; arrows indicate the pattern of reticulations in throat. B. Adult male of B. boans IAvH 14388 (SVL $88.4 \mathrm{~mm}$ ) from Antioquia, Colombia; arrow indicate the uniform pattern in throat. C. Adult female of B. wavrini IAvH 11864 (SVL 101.4 mm) from Bita River, Vichada, Colombia; arrow indicate iris color in life reddish brown. D. Adult male of B. boans IAvH 14386 (SVL $83.6 \mathrm{~mm}$ ) from Antioquia, Colombia; arrow indicate iris color in life golden. E. Dorsal view of heels of Boana wavrini IAvH 11869 (SVL 98.9 mm) from Bita River, Vichada; note the heel appendage with lateral triangular flap. F. Dorsal view of heels of adult male of B. boans IAvH 14388 (SVL $88.4 \mathrm{~mm}$ ) from Antioquia, Colombia; note the heel appendage with small triangular tubercle. Scale bars $=5 \mathrm{~mm}$. Photographs: Andrés Acosta.

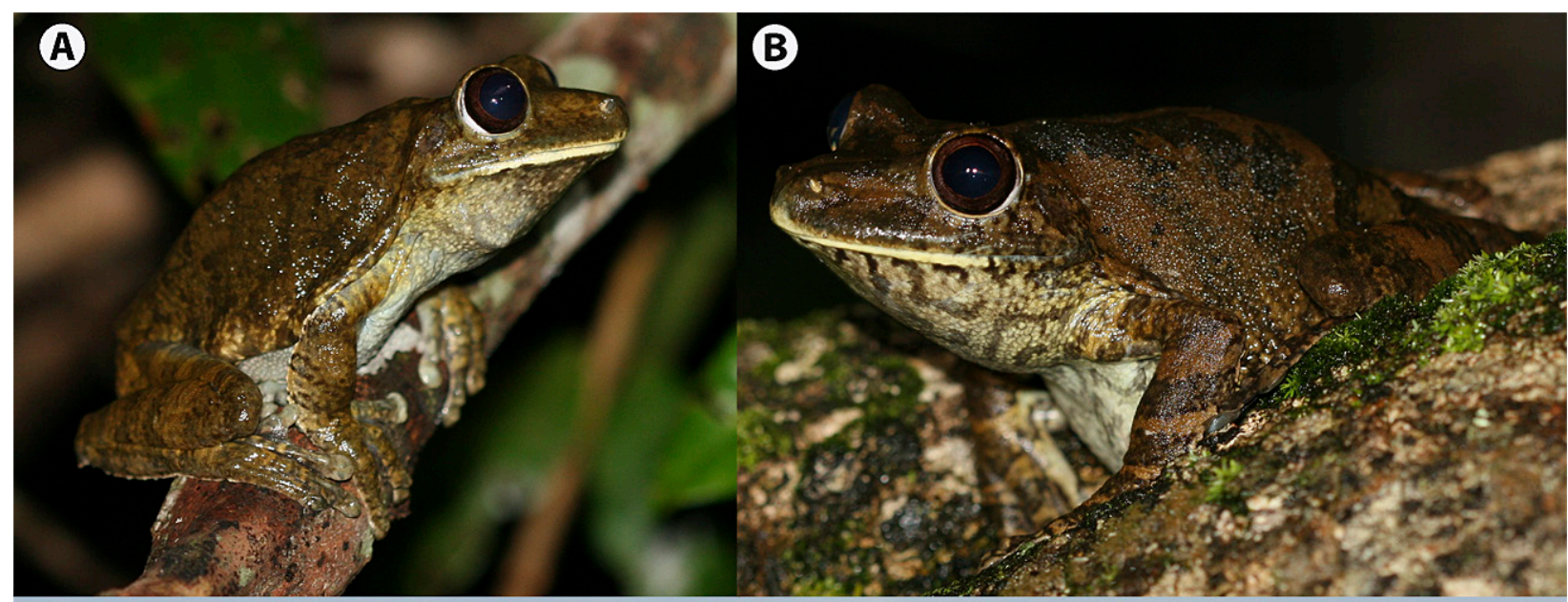

(c)

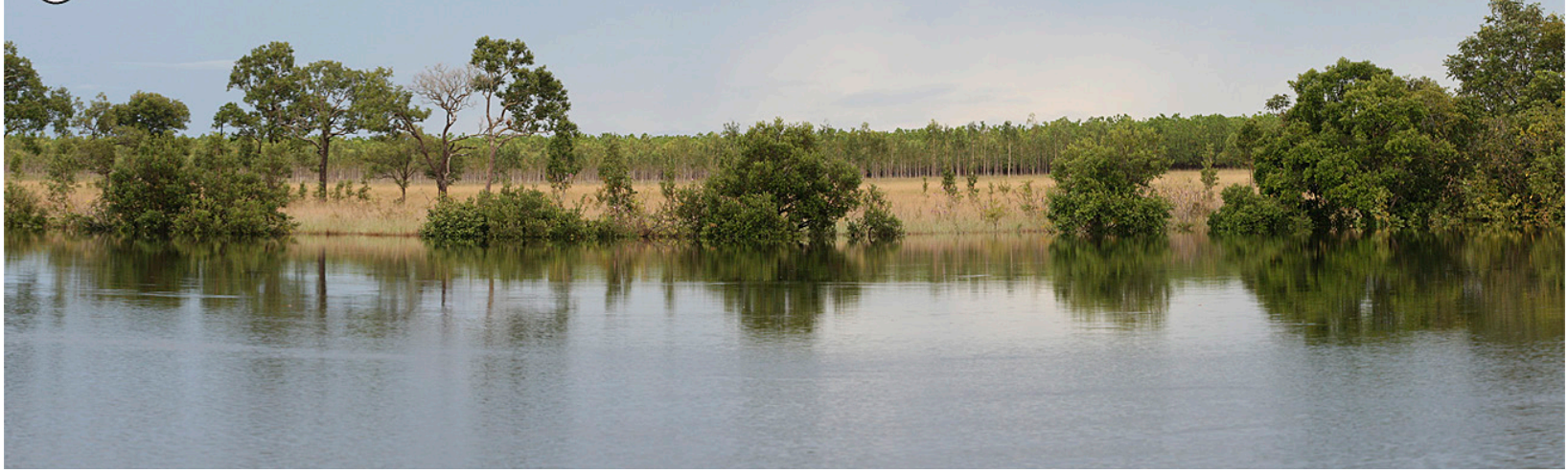

Figure 4. Lateral view of Boana wavrini, adult males. A. IAvH-Am-11586 (SVL 97.7 mm). B. IAvH-Am-11584 (SVL 112.4 mm). C. Habitat in rainy season, from Bita River in Vichada department, Puerto Carreño municipality at Vereda Caño Negro, La Pedregoza Natural Reserve, (site A). Photographs: Andrés Acosta. 


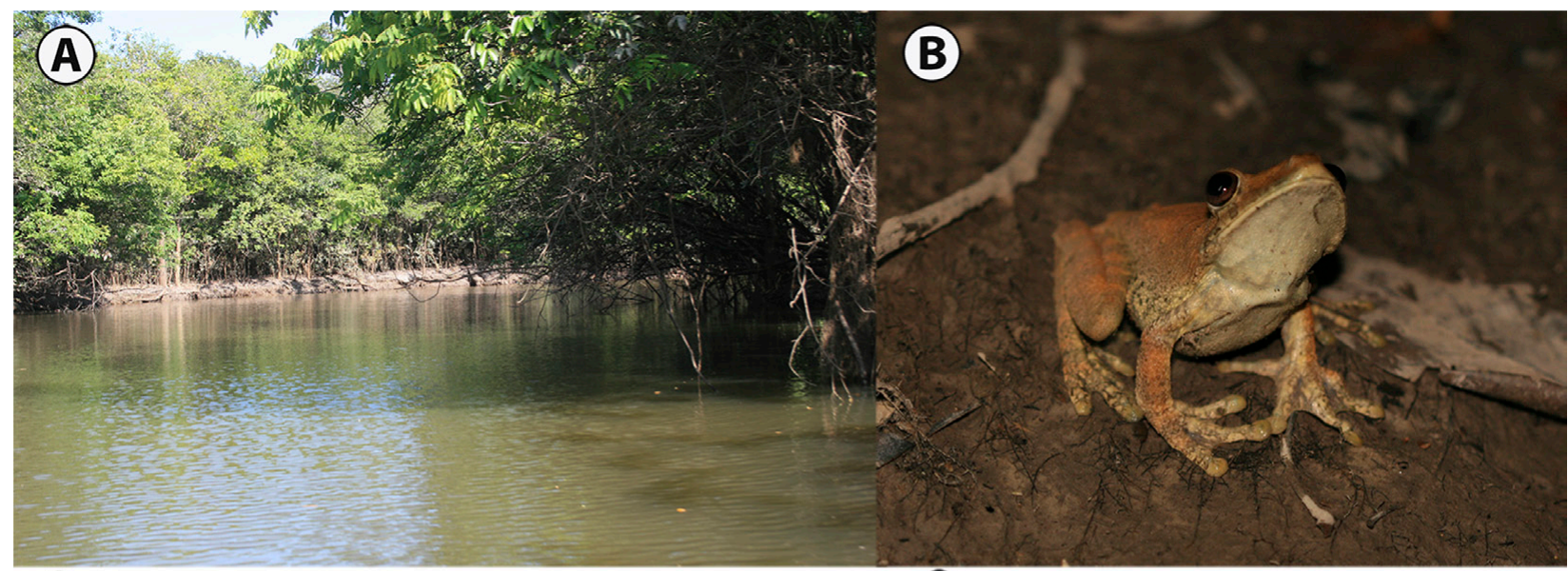

(C)

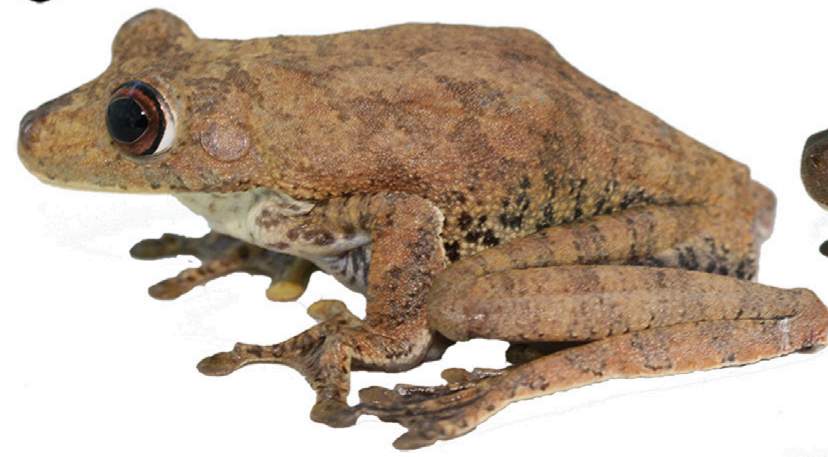

(D)

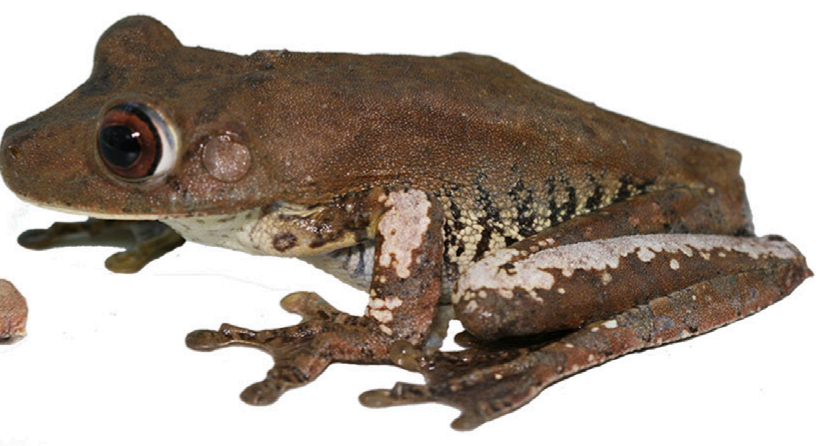

Figure 5. A. Habitat in dry season at La Danta stream from Bita River in Vichada Department, La Primavera municipality (site B). B. Specimen released on the floor on sandbanks La Danta stream. C. Chromatic variation in lateral view of Boana wavrini, at La Danta stream, adult females. IAvH-Am-11854 (SVL 91.7 mm). D. IAvH-Am-11853 (SVL 89.1 mm), Photographs: Andrés Acosta.

name in Colombia and Venezuela for groves of Mauritia flexuosa palm swamps) and open savannas. During nocturnal transects along the sandbank margins of the Bita

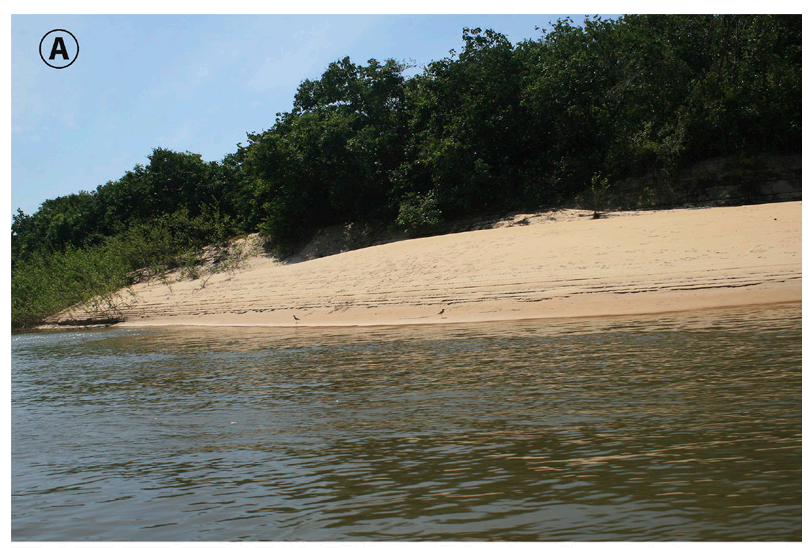

(B)

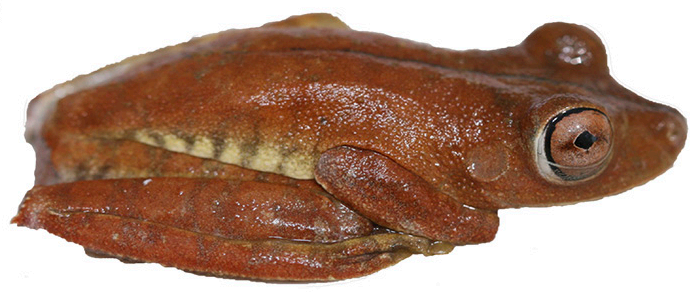

Figure 6. Habitat of juveniles and tadpoles from Boana wavrini in dry season, Bita River in Vichada department, La Primavera municipality. A. Juvenile specimen IAvH-Am-11880 (SVL 36.6 mm) B. Sandbanks at the edge of the Bita River where the specimens were collected. Photographs: Andrés Acosta.
River and 1 of its tributaries (site D, Table 1, Fig. 2), ARA collected a series of 3 adult males (SVL 91.5-102.7 mm) that included a specimen (IAvH-Am-11883, SVL 102.7 $\mathrm{mm}$ ) that lacks the distal extremity of a foot, and 3 juveniles (SVL 21.3-70.5 mm, Fig. 6).

In addition to the above observations, during the dry season (January 2016), IAvH ichthyologists collected a series of tadpoles at different points along the Bita River. A single tadpole (IAvH-Am-11931) was obtained from the shallower sandbank margin of the river (site E, Tables 1, 2, Fig. 2). Two single tadpoles (IAvH-Am-11930, IAvH-Am-11933) were collected in different stages at sampling points very close to the old channel (site F, Table 1, Table 2, Fig. 2) of the Bita River. An aquatic prospection in the shallow shore of Mosco Creek (site G, Table 1, Fig. 2), allowed the collection of several tadpoles IAvH-Am-11934 $(N=11$, stages 26-28

Table 2. Physical and chemical characteristics of water at different points along the Bita River, where Boanas wavrini tadpoles were collected. For details on sampling localities, see Table 1.

\begin{tabular}{|c|c|c|c|c|}
\hline Localities & $\begin{array}{l}\text { Conductivity } \\
\left(\mu \mathrm{S} \cdot \mathrm{cm}^{-1}\right)\end{array}$ & $\begin{array}{c}\text { Temperature } \\
\left({ }^{\circ} \mathrm{C}\right)\end{array}$ & $\begin{array}{c}\text { Dissolved } \\
\text { oxygen } \\
\text { (mg/L) }\end{array}$ & pH \\
\hline site $\mathrm{E}$ & 6.1 & 30.0 & 10.9 & - \\
\hline Site F a & 83.4 & 30.6 & 9.3 & 7.29 \\
\hline Site $\mathrm{Fb}$ & 130.0 & 30.7 & 10.8 & 7.29 \\
\hline Site H & 4.9 & 31.4 & 7.5 & 9.7 \\
\hline
\end{tabular}




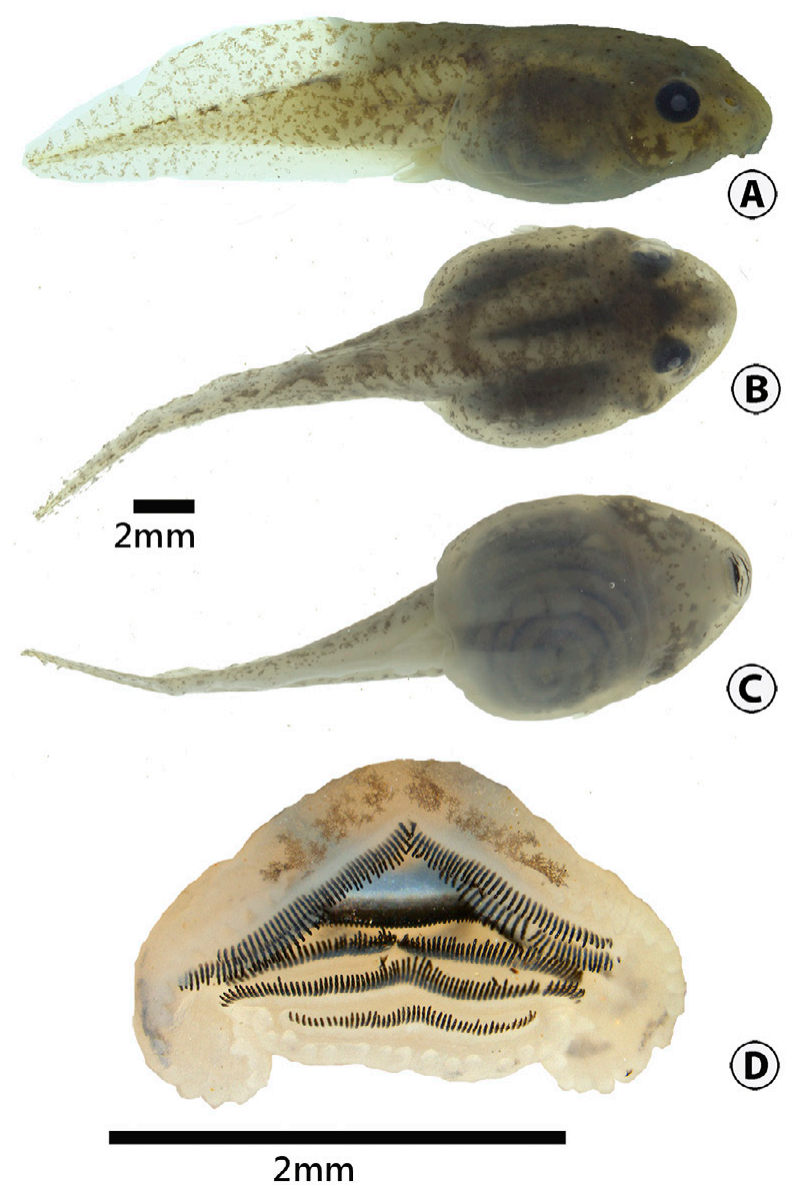

Figure 7. Tadpole of Boana wavrini specimen IAvH 11932 stage 32 sensu Gosner (1960) from El Tijero Creek in Bita River drainage (Vichada). A. Lateral view. B. Dorsal view. C. Ventral view. D. Detail of oral disk. Scale bar $=2 \mathrm{~mm}$. Photograph: Andrés Acosta. sensu Gosner, 1960). Finally, tadpoles IAvH-Am-11932 $(N=3$, Fig. 7) were also collected on a sandbank associated with the mouth of the El Tijero Creek (site H, Table 1, Table 2, Fig. 2). Together, the previously mentioned localities (sites B-G, Table 1, Fig. 2) are geographically close and extend the distribution of $B$. wavrini approximately $122 \mathrm{~km}$ northwest from the distribution in Amazonas state, Venezuela.

During the rainy season (August 2012) ARA heard, recorded and collected (Site A, Figs 2, 4) 3 adult males (SVL 96.4-112.4 mm) calling, from tree tops over flooded shore areas in gallery forests of the Bita River, at about $134 \mathrm{~km}$ northwest from the closest previously reported occurrence in Amazonas State, Venezuela. Complementary field samples during the rainy season (May 2016) obtained just 1 adult female (SVL $104.7 \mathrm{~mm}$, Table 1) from the middle drainage of the Bita River (Site I, Table 1, Fig. 2), in landscapes associated with Mauritia flexuo$s a$ palm swamps, extending the geographic range about $149 \mathrm{~km}$ northwest from a previous occurrence in the state of Amazonas, Venezuela. Simultaneous to the previous field expedition during the rainy season (April and May 2016), LER obtained, during inventories in the eastern region of Arauca Department (Sites J-M, Table 1, Fig. 8 ), the northernmost records of $B$. wavrini that extend its geographic range approximately $283 \mathrm{~km}$ northwest from an occurrence in the state of Amazonas, Venezuela. LER heard vocalizations of a series of 13 specimens and collected a single male (SVL $115.5 \mathrm{~mm}$, Table 1) in gallery forest from Araguato Creek (site J, Table 1, Fig. 8). Four additional specimens were recorded (site K, Table 1, Fig. 8); another 4 specimens were heard (site L, Table

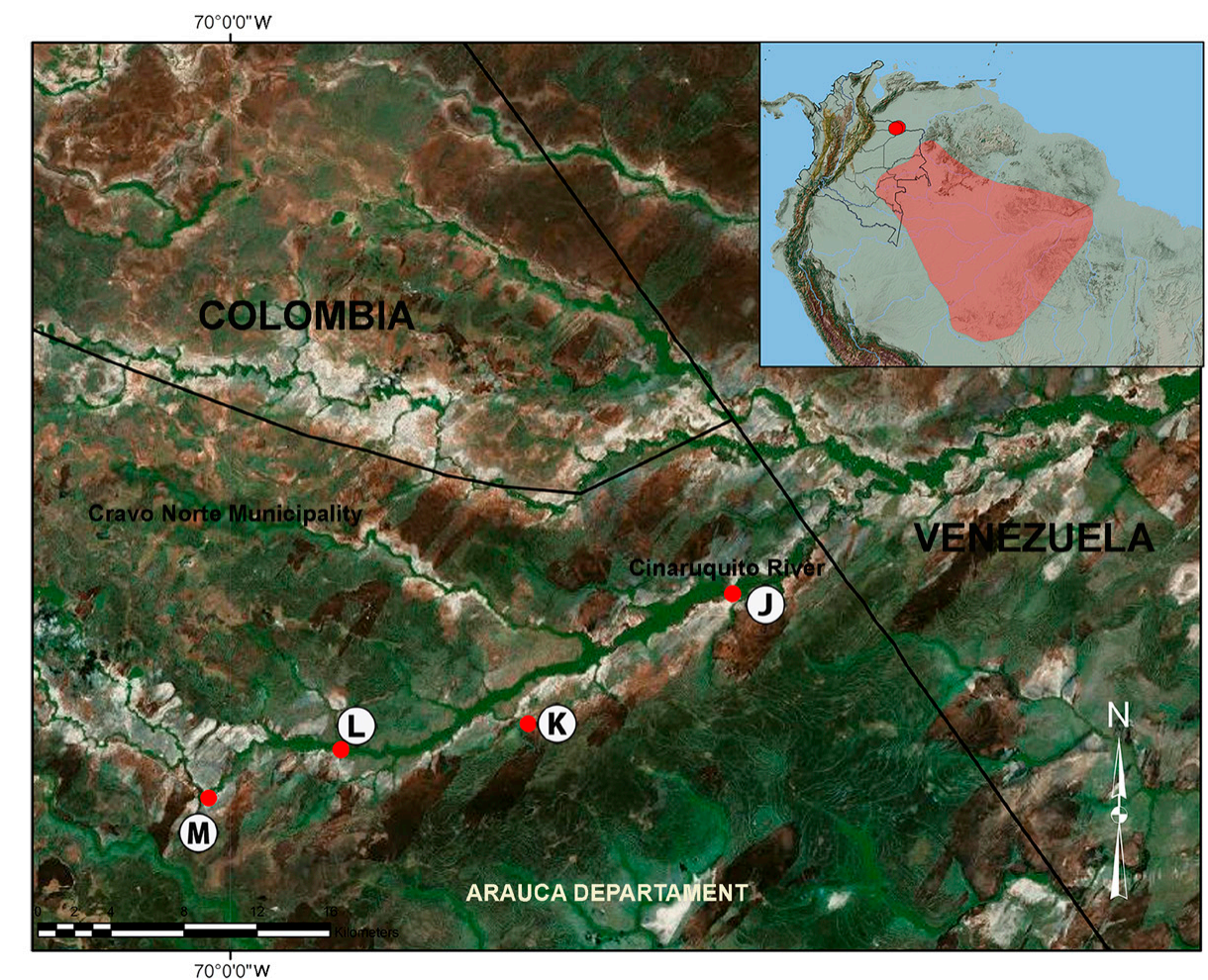

Figure 8. New records of Boana wavrini at Cravo Norte Municipality, Arauca Department, in Llanos of Colombia (Table 1). Site J. Caño Araguato. Site K. La Palmira Farm. Site L. La Aurora Farm. Site M. La Reserva Farm. 
1, Fig. 8) and 2 specimens were recorded (1 of them an adult male collected, SVL $86.3 \mathrm{~mm}$ ) in a gallery forest (site M, Table 1, Fig. 8).

\section{Discussion}

These new records of Boana wavrini from the departments of Arauca and Vichada represent the first records from the Llanos of Colombia and extend the distribution of this species $283 \mathrm{~km}$ north of the nearest previously known occurrences (Fig. 1). As previously observed in populations from Venezuela (Hoogmoed 1990), Brazil (Martins and Moreira 1991), and Colombia (Lynch and Vargas 2000), B. wavrini is a nocturnal riverine species associated with gallery forests and various riparian environments such as morichales (i.e. Mauritia flexuosa palm swamps), creeks, and lagoons.

Four expeditions at different times of the year suggest that $B$. wavrini is asynchronous when compared to other anurans of savannah ecosystems, because this species seems to have higher reproductive activity during the dry season. This is evidenced by an apparent higher abundance and presence of individuals in different stages of development (Table 1), the presence of tadpoles in stages 28-38 (Table 2), and various mating calls recorded at the end of the rainy season (specimen vouchers: IAvHAm-11584-6, IAvH-Am-11858) in Vichada (Bita River). Our observations suggests that reproductive events of $B$. wavrini begin in the dry season at the end of the year, likely extending from December to April, when the water level drops, exposing sandy beaches, which are the reproductive microhabitat of this species. In contrast, most savanna (Llanos) anuran species breed at the beginning of the rainy season (April and May) in more terrestrial environments. Call and reproduction data from Brazilian populations of B. wavrini (Martins and Moreira 1991) corroborate this pattern.

Hoogmoed (1990) evaluated the populations of Venezuela, Brazil, and Suriname and stated that one of the distinctive diagnostic features of $B$. wavrini, compared to other species of the $B$. semilineata group, is their large body size. The SVL of males is $89-113 \mathrm{~mm}$ and of adult females $75-81 \mathrm{~mm}$. Our evaluation of 58 specimens confirms the same pattern observed by Hoogmoed (adult males SVL = 85.6-115 mm; adult females SVL $=80.2$ $109 \mathrm{~mm}$ ). In contrast, in the Amazonian populations of Colombia (Lynch and Vargas 2000) larger specimens were recorded (adult males SVL $=69.0-134.3 \mathrm{~mm}$; adult females SVL = 95.6-132.1 mm).

\section{Acknowledgements}

The Colombian agencies Alexander von Humboldt Biological Resources Research Institute, the Omacha Foundation (Cooperation Agreement Number 15- 14-322.304 CE), Colombia Bio Program of COLCIENCIAS-IAvH (Cooperation Agreement Number FP44842-109-2016 [IAVH 16-062]) and the project "Wildlife" funded by
WCS Colombia and Ecopetrol supported the development of this contribution. We extend special acknowledgements to John D. Lynch who provided valuable information on identification of $B$. wavrini, and Daniel Cuentas for comments on the manuscript. We are grateful to the team of researchers - Carlos Donascimiento Montoya, Juan Gabriel Albornoz, Edwin Lopez, Diana Montoya, Camila Duran Prieto, Cesar Quiroga Giraldo, and Jonathan Bernal—for helping collect specimens during rapid biological assessments of the Bita River drainage (2012-2016). Special thanks to the owners and managers of the La Pedregoza, Anakay, Mi Familia, La Florida, and Rampla Vieja farms for supporting this research and conservation initiative in the municipalities of La Primavera and Puerto Carreño, Vichada, upper and lower drainage of the Bita River and La Palmira and La Aurora farms in Cravo Norte municipality, Arauca. Finally, we thank the anonymous reviewers who with their valuable comments allowed the consolidation of this manuscript and Donald C. Taphorn who kindly and carefully review our English. Specimens were collected from Colombian localities under a permit issued by the Alexander von Humboldt Biological Resources Research Institute (IAvH) (Decree 1376 of 2013).

\section{Authors' Contributions}

ARA and LER collected the specimens, reviewed literature and wrote the text; ARA reviewed the museum specimens, made the morphological measurements, and analyzed the data.

\section{References}

Acosta-Galvis AR (2000) Ranas, salamandras y Caecilias (Tetrapoda: Amphibia) de Colombia. Biota colombiana 1 (3): 289-319. https:// doi.org/10.21068/bc.v1i3.80

Acosta-Galvis AR (2017) Lista de los Anfibios de Colombia: Referencia en línea V.07.2017.0. Página http://www.batrachia.com. Accessed on: 2017-02-12.

Faivovich J, Haddad CFB, Garcia PCA, Frost DR, Campbell JA, Wheeler WC (2005) Systematic review of the frog family Hylidae, with special reference to Hylinae: a phylogenetic analysis and taxonomic revision. Bulletin of the American Museum of Natural History 294: 1-240. http://doi.org/bmtn6r

Frost DR (2017) Amphibian Species of the World: an Online Reference. Version 6.0 (21 Jan 2017). American Museum of Natural History, New York. http://research.amnh.org/herpetology/amphibia/index. html. Accessed on: 2017-02-16.

Gorzula S, Señaris JC ("1998”) [1999] Contribution to the herpetofauna of the Venezuelan Guayana I. A database. Scientia Guaianae 8: ixviii, 1-269.

Gosner KL (1960) A simplified table for staging anuran embryos and larvae with notes on identification. Herpetologica 16 (3): 183-190.

Hoogmoed MS (1990) Resurrection of Hyla wavrini Parker (Amphibia: Anura: Hylidae), a gladiator frog from northern South America. Zoologische Mededelingen 64 (6): 71-93.

Lynch JD, Vargas-Ramirez MA (2000) Lista preliminar de especies de anuros del Departamento del Guainía, Colombia. Revista de la Academia Colombiana de Ciencias Exactas, Físicas y Naturales 24 (93): 579-589.

Lynch JD, Suárez-Mayorga AM (2001) The distributions of the gladiator 
frogs (Hyla boans group) in Colombia, with comments on size variation and sympatry. Caldasia 23 (2): 491-507.

Lynch JD, Suárez-Mayorga AM (2011) Clave ilustrada de los renacuajos en las tierras bajas al oriente de los Andes con énfasis en Hylidae. Caldasia 33 (1): 235-270.

Martins M, Moreira G (1991) The nest and the tadpole of Hyla wavrini,
Parker (Amphibia, Anura). Memorias do Instituto Butantan 53: 197-204.

Ruiz-Carranza PM, Ardila-Robayo MC, Lynch JD (1996) Lista actualizada de la fauna de Amphibia de Colombia. Revista de la Academia Colombiana de Ciencias Exactas, Físicas y Naturales 20 (77): 365-415. 